\title{
Comparative study on physicochemical status and diversity of macrophytes and zooplanktons of two urban ponds of Chandannagar, WB, India
}

\author{
Rituparna Sarkar ${ }^{1} \cdot$ Apurba Ratan Ghosh ${ }^{2} \cdot$ Naba Kumar Mondal $^{2}$
}

Received: 14 November 2018 / Accepted: 16 January 2020 / Published online: 25 January 2020

(c) The Author(s) 2020

\begin{abstract}
Present investigation has made an attempt to assess the variations in physicochemical status of two urban ponds (constructed boundary: Pond A and natural boundary: Pond B) of Chandannagar and also established the variations in the diversity of macrophytes and zooplankton of the study areas during winter (Nov-Dec, 2017). Limnological parameters recorded from two spots collected in three phases, such as temperature, $\mathrm{pH}$, transparency, conductivity, DO, BOD, total dissolved solids (TDS), total suspended solids (TSS), total alkalinity, total hardness and chloride, were evaluated. From this observation, it is reported that there are marked variations in different water quality parameters of two urban ponds during the study period. The value of water temperature in Pond $\mathrm{A}$ and $\mathrm{B}$ was 22.0 and $21.3^{\circ} \mathrm{C}$, respectively. $\mathrm{pH}$ value (7.9) was highest in Pond B. Pond B water was more turbid than Pond A. The highest values of other parameters like conductivity $(218.50 \mu \mathrm{S} / \mathrm{cm})$ DO $(8.47 \mathrm{mg} / \mathrm{l})$, BOD $(5.69 \mathrm{mg} / \mathrm{l})$, TDS $(135.19 \mathrm{mg} / \mathrm{l})$, TSS $(67.60 \mathrm{mg} / \mathrm{l})$, total alkalinity $(181.15 \mathrm{mg} / \mathrm{l})$, total hardness $(145.66 \mathrm{mg} / \mathrm{l})$ and chloride $(58.94 \mathrm{mg} / \mathrm{l})$ were found in case of Pond B. Maximum macrophytic vegetations were found in Pond B in comparison with Pond A. The study of the zooplankton community reveals that the maximum occurrence of rotifers in Pond B indicates pollution status.
\end{abstract}

Keywords Physicochemical status · Macrophytes · Zooplankton · Urban ponds

\section{Introduction}

All living organisms on this planet need water for their growth and survival. Almost every aspect of life on our planet is governed by water. Freshwater is not only a finite resource but also essential for agriculture, industry and even human existence, and without its inadequate quantity and quality, sustainable development will not be possible (Kumar 1997). The deterioration of water quality of freshwater resource is becoming faster which leads to a global problem (Mahananda et al. 2005). Discharge of toxic chemicals over extraction of aquifer and contamination water body with unwanted substances excessive

Naba Kumar Mondal

nkmondal@envsc.buruniv.ac.in

1 Department of Environmental Science, Chandernagore College, Chandannagar, Hooghly, WB 712 136, India

2 Department of Environmental Science, The University of Burdwan, East Bardhaman, WB 713 104, India algal growth are some of the major causative agents of water quality degradation. Several researchers (Ghose and Basu 1968; Patil and Tijare 2001; Singh and Mathur 2005: Gupta and Shukla 2006) observed that freshwater is gradually becoming a scarce commodity due to exorbitant pollution, over exploitation, etc. Dwivedi and Pandey (2002) reported that industrial waste water, sewage and municipal wastes are being continuously added to water reservoirs which affect the physicochemical quality of water and also making them unfit for even use of livestock and other organisms. Uncontrolled discharge of domestic waste water into the ponds has resulted in eutrophication of ponds (Pandey and Pandey 2003). The added unwanted substances may be arbitrarily classified as biological, chemical, physical and radiological impurities in addition to industrial wastes, commercial solvents, metal, acid, salts, sediments, pesticides, herbicides, plant nutrients, radioactive materials, decaying animal bodies, vegetable matters and living microorganisms (Gay and Proop 1993). All these impurities result in degradation of water quality, like bad taste, colour, odour, turbidity, 
hardness, corrosiveness, staining and frothing. Ponds which are relatively small in size are important part of our urban ecosystem, and they perform several environmental, social and economic functions, viz. as a source of drinking water, recharging groundwater, acting as sponges to control flooding, supporting biodiversity and providing livelihoods (Saha et al. 2017). Ponds have been used since time immemorial as a traditional source of water supply in India. However, the water of the ponds, lakes and rivers is polluted mainly due to discharge of waste water from the residential areas, sewage outlets, solid wastes, detergents, automobile oil wastes, fishing facilities and agricultural pesticides from farmlands (Hassan et al. 2013). Natural water bodies may contain different types of impurities in the different forms, such as weathering of rocks and leaching of soils, dissolution of aerosol particles from the atmosphere and from several human activities (Adeyeye 1994). Both the phytoplankton and zooplankton communities influence the water quality characteristics and are important components in the production of standing waters. The macrophyte, the aquatic plant grows in or near the water bodies, plays an important role for maintaining the ecological balance and resilience (Dykyjova 1971, 1978; Adams and McCraken 1974; Pandit 1984) and also are key factors for primary production of an aquatic ecosystem (Dhore and Lachure 2014; Bhute and Harney 2017). Macrophytes are of several types: emergent, rooted submerged, free submerged and free floating. Macrophytes also serve as indicator species responding to changes in water quality and contaminants to cause pollution in several ecosystems (Best 1982). Different studies have been done on aquatic macrophytes from different freshwater bodies by different researchers (Unni 1971; Crowder et al. 1977; Zutshi et al. 1980; Billore and Vyas 1981; Dey and Kar 1989; Islam 1990; Kodarkar 1996; Salaskar 1998; Bhaumik et al. 2004, Kumar and Pandit 2005; Ghavzan et al. 2006; Devi and Sharma 2007). Transparency, nutrient concentration and land are the different factors responsible for proper growth and distribution of macrophytes in the reservoirs and rivers (Bini et al. 1999; Akasata et al. 2010). Zooplankton is a heterotrophic planktonic community floating in water and acts as important food source for many aquatic organisms. Besides this, zooplankton also serves as an indicator organism of water type, fish yield, and/or total biological production. Distribution of zooplankton species is influenced by abiotic and biotic factors, viz. temperature, dissolved oxygen, salinity and other physicochemical characteristics (Jeje and Fernando 1986). Balarabe (1989) reported that zooplankter is primary consumers feeding mainly on phytoplankton and is regarded as secondary producers in the tropic structure of an aquatic ecosystem. The ecology of zooplankton diversity in aquatic bodies has been carried out by several workers (Gulati 1964; Mathew 1978; Suganan 1997; Jha 1997; Kumar et al. 2007; Tripathi et al. 2008a, b). The relationship between the physicochemical parameters and plankton production of water bodies was studied intensively by Kutama et al. (2011) and Hassan et al. (2013).

The present study mainly focuses on the contamination status and effects of contamination coming from the human settlements into two urban ponds (A and B) of Chandannagar, Hooghly, out of which one has a constructed boundary and the other bears a natural boundary. This study endorses some important limnological parameters like temperature, $\mathrm{pH}$, transparency, conductivity, DO, BOD, total dissolved solids (TDS), total suspended solids (TSS), total alkalinity, total hardness and chloride. The present study intended to highlight the diversity of flora and fauna, i.e. variations of macrophytic vegetations and zooplankton species of the selected ponds (Ponds A and B) during the study period (Nov-Dec, 2017).

\section{Materials and methods}

\section{Description of study area}

Chandannagar, formerly known as Chandernagore, is a Corporation city and former French colony located $35 \mathrm{~km}$ north of Kolkata, in West Bengal, India. It is situated at $22.87^{\circ} \mathrm{N}$ latitude and $88.38^{\circ} \mathrm{E}$ longitude and $16 \mathrm{~m}$ elevation above the sea level. The water samples for physicochemical analysis were collected between 11.00 am to 12.00 noon during winter season (Nov-Dec, 2017) from two urban ponds: Pond A is located near Madhyanchal region of Chandannagar with constructed boundary used for household and fishing purposes by the local people, and the Pond B is located at colony area of Subhash Palli, Chandannagar, having natural boundary admitting common human activities like bathing, washing of clothes and washing of animals which in turn add nutrients to water and alter the quality of water. Samples were collected in three phases during entire study period (Nov-Dec, 2017) of total 60 days.

\section{Collection of water samples for analysis of limnological parameters}

The samples were collected in plastic container from a depth of 5-10 $\mathrm{cm}$ below the surface water of each pond in three phases. The physicochemical characteristics of water like temperature, $\mathrm{pH}$, transparency, conductivity, dissolved oxygen (DO), biochemical oxygen demand (BOD), total dissolved solids (TDS), total suspended solids (TSS), total alkalinity, total hardness, and chloride were determined in winter by following standard methods of APHA (1998). Temperature, $\mathrm{pH}$, transparency, conductivity, $\mathrm{DO}$ of the water of two 
ponds were measured at their collection sites. Temperature was recorded with the help of mercury thermometer, $\mathrm{pH}$ was recorded by hand $\mathrm{pH}$ meter, water transparency was measured by using black and white disc, and conductivity was measured by using hand conductivity meter (EC TESTER), whereas DO was measured by following Winkler's iodometric method. For the measurement of other physicochemical parameters, water samples were collected in plastic sampling bottles and transported to the laboratory. All the water samples collected in three phases during winter were analysed and expressed as Mean \pm SD.

\section{Collection of macrophytes}

The aquatic macrophytes were also collected from two urban ponds (A and B) during the winter (Nov-Dec, 2017) season. Macrophytes of shallow waters were collected directly, while the others of deeper water with the help of long handled hook. After collection, the specimens were washed thoroughly and soaked with filter paper and kept in polythene bags and brought to the laboratory for identification by using the method adopted by Cook (1996) and Kodarkar (1996).

\section{Analysis of zooplankton species}

For zooplankton analysis, specimens were collected from two urban ponds (A and B) with plankton net having mesh size of $50-55 \mu \mathrm{m}$ and then preserved in $4 \%$ formaldehyde solution. The zooplankter was observed under microscope, and taxonomic identification was done following the literature of Edmondson (1959), Sehgal (1983), Jeje and Fernando (1986), Sharma and Michael (1987), Battish (1992), Sharma (1998) and Venkataraman (1999).

\section{Results and discussion}

Comparative study on physicochemical data of two urban ponds (A and B) of Chandannagar was recorded after collecting and analysed the water samples in three phases, and the Mean \pm SD values of different water quality parameters are shown in Table 1.

The present study mainly focuses the variations of water quality of two urban ponds during winter (Nov-Dec, 2017). The importance of physicochemical parameters in assessing water quality is well established (Mitra 1995; Kataria et al. 1996; Kudesia 2000; Sunkad 2008) (Tables 2, 3).

Murugesan et al. (2004) reported that the increasing water temperature was responsible for increasing the chemical and biological reaction in water body and reducing the solubility of gases. During the present investigation, there was no
Table 1 Variations in the physicochemical parameters of water samples collected from two urban Ponds (A and B) of Chandannagar during the study period (Nov-Dec, 2017)

\begin{tabular}{lcc}
\hline Parameters & $\begin{array}{l}\text { Pond A } \\
\text { (constructed } \\
\text { boundary) }\end{array}$ & Pond B (natural boundary) \\
\hline Temperature $\left({ }^{\circ} \mathrm{C}\right)$ & $22.0 \pm 0.07$ & $21.3 \pm 0.14$ \\
pH & $7.5 \pm 0.12$ & $7.9 \pm 0.19$ \\
Transparency $(\mathrm{cm})$ & $63.0 \pm 2.05$ & $51.5 \pm 1.58$ \\
Conductivity $(\mu \mathrm{S} / \mathrm{cm})$ & $123.11 \pm 21.2$ & $218.50 \pm 33.1$ \\
DO $(\mathrm{mg} / \mathrm{l})$ & $5.80 \pm 0.60$ & $8.47 \pm 1.18$ \\
BOD $(\mathrm{mg} / \mathrm{l})$ & $2.79 \pm 0.41$ & $5.69 \pm 0.52$ \\
TDS $(\mathrm{mg} / \mathrm{l})$ & $118.33 \pm 20.21$ & $135.19 \pm 24.56$ \\
TSS $(\mathrm{mg} / \mathrm{l})$ & $51.52 \pm 12.38$ & $67.60 \pm 15.08$ \\
Total alkalinity $(\mathrm{mg} / \mathrm{l})$ & $167.80 \pm 23.39$ & $181.15 \pm 37.56$ \\
Total hardness $(\mathrm{mg} / \mathrm{l})$ & $128.30 \pm 16.25$ & $145.66 \pm 28.17$ \\
Chloride $(\mathrm{mg} / \mathrm{l})$ & $35.20 \pm 4.11$ & $58.94 \pm 5.116$
\end{tabular}

Values are mean \pm SD (3 samples during study period)

$D O$ dissolved oxygen, $B O D$ biochemical oxygen demand, TDS total dissolved solids, TSS total suspended solids

significance difference in temperature of the water of two ponds (A and B).

$\mathrm{pH}$ is an important parameter which helps to determine the acid-base balance of river water (Bhalla and Waykar 2012). $\mathrm{pH}$ of water helps to determine the corrosive nature of water. Lower the $\mathrm{pH}$ value higher is the corrosive nature of water. The $\mathrm{pH}$ of water affects the solubility of many toxic and nutritive chemicals and so the presence of these substances in any aquarium system affects the aquatic organism and $\mathrm{pH}$ is also positively correlated with electrical conductance and total alkalinity (Gupta et al. 2009). Karanth (1987) reported that the higher $\mathrm{pH}$ values indicated the carbon dioxide and carbonate-bicarbonate equilibrium was affected more due to change in physicochemical condition. The permissible level of $\mathrm{pH}$ in drinking water is 6.5 to 8.5. In case of both Ponds $\mathrm{A}$ and $\mathrm{B}$, the value of the $\mathrm{pH}$ indicates the alkaline in nature and also within permissible limit.

Dokulil et al. (2006) reported that water transparency was not only a crucial parameter of lake optics but also one of the important indexes of eutrophication evaluation of lake which directly reflect the lake limpid and muddy degree and was affected by suspended solids and phytoplankton of water. Water transparency was shown higher in Pond A than in Pond B. Water transparency is mainly affected by the factors like rainfall, Sun's position in the sky, angle of incidence of rays, cloudiness, visibility, turbidity and planktonic growth. High turbidity is responsible for damages to benthic community (Anitha 2002).

Conductivity is a measure of the ability of an aqueous solution to carry an electric current. It depends on the presence of ions, on their total concentration, mobility and

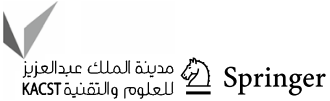


Table 2 Variations in aquatic macrophyte vegetations of two urban ponds (A and B) of Chandannagar recorded during the study period (Nov-Dec, 2017)

\begin{tabular}{lllll}
\hline Name of the macrophytes & Family & Types & Pond A & Pond B \\
\hline Ipomoea sp. & Convolvulaceae & Emergent & + & + \\
Hydrilla sp. & Hydrochorideae & Rooted submerged & + & + \\
Ceratophyllum sp. & Ceratophyllaceae & Free submerged & + & + \\
Eichhornia sp. & Pontederiaceae & Free floating & - & + \\
Lemna sp.(Major) & Lemnaceae & Free floating & - & + \\
Lemna sp. (Minor) & Lemnaceae & Free floating & - & + \\
Pistia sp. & Araceae & Free floating & + & + \\
Azolla sp. & Salviniaceae & Free floating & - & + \\
Nymphaea sp. & Nymphaeaceae & Rooted free floating leaves & - & + \\
\hline
\end{tabular}

$(+)=$ Present $(-)=$ Absent
Table 3 Variations in zooplankton specimens of two urban ponds (A and B) of Chandannagar recorded during the study period (Nov-Dec, 2017)

\begin{tabular}{|c|c|c|c|c|}
\hline $\begin{array}{l}\text { Name of the zoo- } \\
\text { plankton }\end{array}$ & Phylum & Family & Pond A & Pond B \\
\hline Brachionus sp. & Rotifera & Brachionidae & - & + \\
\hline Keratella sp. & Rotifera & Brachionidae & - & + \\
\hline Cyclops sp. & Arthropoda & Cyclopidae & + & + \\
\hline Cypris sp. & Arthropoda & Cyprididae & - & - \\
\hline Diaptomus sp. & Arthropoda & Diaptomidae & + & - \\
\hline Bosmina sp. & Arthropoda & Bosminidae & + & - \\
\hline Daphnia sp. & Arthropoda & Daphniidae & + & + \\
\hline Moina sp. & Arthropoda & Moinidae & + & - \\
\hline
\end{tabular}

$(+)=$ Present $;(-)=$ Absent

valence and on the temperature of measurement. Electrical conductivity is found to be good indicator of water quality (Gaikwad et al. 2008). Sastry et al. (1999) found the concentration of dissolved solids to be proportional to the ionic strength and proposed that the increase in conductivity may be due to leachate infiltration from soil. Conductivity of Pond A $(123.11 \mu \mathrm{S} / \mathrm{cm})$ was lower than Pond B $(218.50 \mu \mathrm{S} /$ $\mathrm{cm})$.

DO is one of the most important parameters of water quality analysis. The amount of oxygen dissolved in a reservoir is affected by temperature of water, salinity, altitude, water inflow and photosynthetic activity of algae and plants (George et al. 2004; Abowei 2010). In the progress of summer, dissolved oxygen decreased due to increase in temperature and microbial activity (Moss 1972; Morrissette and Mavinic 1978). Dokulil et al. (2006) reported that the fluctuation in dissolved oxygen was caused by biological processes and formation of eutrophication of water. Do level was found within optimum range in case of Pond A, i.e. $5.80 \mathrm{mg} / \mathrm{l}$ but high in case of Pond B $(8.47 \mathrm{mg} / \mathrm{l})$.

Biochemical oxygen demand determination (BOD) is the amount of dissolved oxygen required for the biochemical decomposition of organic compounds by microorganisms and oxidation of certain inorganic materials. BOD determination is used for assessing the organic pollution (Barai and Kumar 2013) and also used for the measurement of the amount of organic materials of an aquatic system supporting the growth of microorganisms (Keramat 2008). BOD level was found $2.79 \mathrm{mg} / \mathrm{l}$ in Pond A but $5.69 \mathrm{mg} / \mathrm{l}$ in Pond B. So, water of Pond A may be used for domestic purposes but not Pond B.

Total dissolved solids (TDS) is an important parameter in determining the water quality standards, and it accounts for the various types of solids in dissolved form which may be organic or inorganic (Jayakumar et al. 2009). Several researchers (Bharathi and Krishnamoorthy 1990; Tripathy and Adhikary 1990) reported that TDS is proportional to the degree of pollution. TDS were maximum during summer and minimum during monsoon (Narayan et al. 2007; Jacklin Jemi and Regini Balasingh 2011). During the present study period, maximum value of total dissolved solids was recorded in case of Pond B $(135.19 \mathrm{mg} / \mathrm{l})$ and minimum in case of Pond A $(118.33 \mathrm{mg} / \mathrm{l})$. In water, total dissolved solids are composed mainly of carbonates, bicarbonates, chlorides, phosphates, nitrates organic matter, salt and other particles.

Total suspended solids (TSS) are solids in water that can be trapped by a filter. TSS can include a wide variety of materials, viz. silt, decaying plant and animal matter, industrial wastes, and sewage. High concentrations of suspended solids can cause many problems for stream health and aquatic life. Total suspended solids (TSS) in case of both Ponds A and B were found to be of $51.52 \mathrm{mg} / \mathrm{l}$ and $67.60 \mathrm{mg} / \mathrm{l}$, respectively.

Alkalinity is a capacity of water which helps to neutralize a strong acid (Shinde et al. 2011). Anions, viz. carbonate $\left(\mathrm{CO}^{3-}\right)$, bicarbonate $\left(\mathrm{HCO}^{3-}\right)$, hydroxyl $\left(\mathrm{OH}^{-}\right)$, phosphate $\left(\mathrm{PO}^{-3-}\right)$ and silicate $\left(\mathrm{SiO}^{4-}\right)$, are contributed alkalinity to water. Boyd (1982) reported that the uptake or release of carbon dioxide by organisms might change the proportion of carbonates and bicarbonates in water. During summer the concentration of nutrient increased the alkalinity of water (Arasu et al. 2007), but the alkalinity became 
decreased in monsoon due to dilution of rainwater (Shinde et al. 2010). Total alkalinity of Pond A (167.80 mg/l) was found to be lower than Pond B $(181.15 \mathrm{mg} / \mathrm{l})$.

Hardness is an important parameter for detecting water pollution. According to Baruah et al. (1993) and Rao (2001), total hardness of water indicates the water quality in terms of calcium and magnesium only. In the present investigation, the hardness of Ponds $\mathrm{A}$ and $\mathrm{B}$ was $128.30 \mathrm{mg} / \mathrm{l}$ and $145.66 \mathrm{mg} / \mathrm{l}$, respectively. So, it was moderate hardness in both the cases.

Chloride anion is generally present in natural waters. Prakash (2004) reported that in natural freshwater, high concentration of chloride is regarded as an indicator of pollution. Human and animal excreta and also industrial effluents are bearing huge quantities of chlorides along with nitrogenous compounds (Naik and Purohit 1997). Chloride concentration is higher in organic wastes and its higher concentration in natural water is a definite indication of pollution from domestic sewage. The ecological significance of chloride lies in its potential to regulate salinity of water. The chloride content of water samples of Pond A was $35.20 \mathrm{mg} / \mathrm{l}$ but in Pond B was $58.94 \mathrm{mg} / \mathrm{l}$. Due to constructed boundary of Pond A restricted entry of the sewage run-off from the streets but due to natural boundary Pond B failed to restrict the surface run-off which leads to substantially higher levels of chloride content in the water.

Several researchers (Skubinna et al. 1995; Melzer 1999; Penning et al. 2008; Sondergaard et al. 2010; Poikane et al. 2015) reported that macrophytes are important structural components and bioindicators of freshwater lakes, and its occurrence and species composition are dependent on the nutrient conditions, water level, water temperature and transparency. Variations in macrophyte species is affected by changing environmental conditions (Short and Neckles 1999; Rooney and Kalff 2000; Silva et al. 2008). Aquatic macrophytes not only play an important role in maintenance of aquatic ecosystem, but also they absorb different dissolved nutrients, nitrogen and phosphorus from polluted water in maintaining the resilience of ecosystem. The study of the macrophytes gives us valuable information and also maintains healthy aquatic environment. But on the other hand, when the macrophytes are present in surplus amount, they not only reduce productivity of aquatic system, accumulate silts but also produce huge amount of nutrients causing death, pollute water and produce foul odour and smell (Wahane et al. 2017). During the field survey various type of macrophytes, e.g. emergent (Ipomoea sp.), rooted submerged (Hydrilla sp.), free submerged (Ceratophylum sp.) and free floating (Eichhornia sp., Lemna sp., Pistia sp., and Azolla sp.), have been observed. Maximum macrophytes were found in Pond B than in Pond A due to efficient and adequate nutrients coming from different sources. The presence of Lemna sp. and Eichhornia sp. also indicates the pollution load in Pond B.

Zooplankton species inhabits in the freshwater habitats of the world, including polluted water bodies caused by industrial and municipal waste waters (Mukhopadhyay et al. 2007). The diversity and density of each genus of zooplankton varied in each pond. Usually the number of zooplankton increases with the early rainy season and gradually declines as the rainy season progresses (Balarabe 1989; Agwigo 1997). Here, the maximum zooplankton species was found in Pond A. But the presence of rotifers signifies the pollution status of Pond B.

\section{Conclusion}

The study evaluated the water quality of two different kinds of ponds of Chandannagar, Hooghly, WB, and a comparative assessment of certain important physicochemical parameters like temperature, $\mathrm{pH}$, transparency, conductivity, DO, BOD, TSS, TDS, total alkalinity, total hardness, chloride, and also diversity of macrophytes and zooplankton community was done. Analysis of physicochemical parameters is very essential and important to test the water before it is used for domestic, agricultural, industrial or any other purposes. Therefore, it is necessary that the quality of domestic and drinking water should be checked. Comparatively highest level of pollution status was observed in Pond B than in Pond A due to the presence of some macrophytes (Eichhornia and Lemna) and rotifers (Brachionus and Keratella).

Acknowledgements The authors express their deep sense of gratitude to Principal, Chandernagore College, Chandannagar, Hooghly, West Bengal, India, for providing necessary laboratory facilities.

Open Access This article is licensed under a Creative Commons Attribution 4.0 International License, which permits use, sharing, adaptation, distribution and reproduction in any medium or format, as long as you give appropriate credit to the original author(s) and the source, provide a link to the Creative Commons licence, and indicate if changes were made. The images or other third party material in this article are included in the article's Creative Commons licence, unless indicated otherwise in a credit line to the material. If material is not included in the article's Creative Commons licence and your intended use is not permitted by statutory regulation or exceeds the permitted use, you will need to obtain permission directly from the copyright holder. To view a copy of this licence, visit http://creativecommons.org/licenses/by/4.0/.

\section{References}

Abowei JFN (2010) Salinity dissolved oxygen, $\mathrm{pH}$ and surface water temperature conditions in Nkoro River, Niger Delta, Nigeria. Adv J Food Sci Technol 2(1):36-40

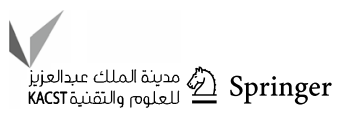


Adams MS, McCraken MD (1974) Seasonal production of the Myriophyllum component of the littoral of lake Wingra, Wisconsin. J Ecol 62:457-467

Adeyeye EI (1994) Determination of heavy metals in Illisha Africana, associated Water, Soil Sediments from some fish ponds. Int J Environ Study 45:231-240

Agwigo JN (1997) Studies on plankton productivity in relation to water quality parameters and nutrients level. J Aquat Sci 12:15-22

Akasata M, Takamura N, Mitsuhashi H, Kadrao Y (2010) Effects of land use on aquatic macrophytes diversity and water quality of ponds fresh boil. Freshw Biol 55:902-922

Anitha G (2002) Hydrography in relation to benthic macroinvertebrates in Mir-Alam Lake Hyderabad Andhra Pradesh, India. Ph.D. Thesis submitted to Osmania University, Hyderabad

APHA, AWWA, WPCF (1998) Standard methods for the examination of water and wastewater, 20th edn. American Public Health Association, Washington

Arasu PT, Hema S, Neelakantan MA (2007) Physico-chemical analysis of Tamirabarani river water in south India. Indian J Sci Technol 1(2):1-5

Balarabe ML (1989) Limnology and Zooplankton distribution of Makwaye (ABU University Farm) Lake Samaru Zaria. Unpublished M.Sc. Thesis. Department Of Biological Sciences ABU Zaria. 164

Barai SR, Kumar S (2013) Evaluation of the physico-chemical characteristics of river Varuna at Varanasi, India. JEB 34:259-265

Baruah AK, Sharma RN, Borah GC (1993) Impact of sugar mill and distillery effluents on water quality of river Gelabil, Assam. Indian J Environ Health 35:288-293

Battish SK (1992) Freshwater zooplankton of India. Oxford and IBH Publishing Co., New Delhi, p 233

Best EPH (1982) Effects of water pollution on freshwater submerged macrophytes. In: Arsh V, Ney CK (eds) Water Pollution and Management Reviews. South Asia Publishers, NewDelhi, pp $27-56$

Bhalla R, Waykar B (2012) Physicochemical profile of the Godavari River at Nashik in context of pollution. The Ecoscan 6(1\&2):29-34

Bharathi SG, Krishnamoorthy SR (1990) Effect of industrial effluents on river Kali around Dandeli, Karnataka, Part I- Physicochemical complexes. Indian J Environ Health 32:167-171

Bhaumik U, Das P, Paria T (2004) Macrophytes and Macrophyte Associated Fauna in a floodplain wetland system of West Bengal having both open and close characteristics. Environ Ecol 22(Sp12):371

Bhute KB, Harney NV (2017) Macrophytes biodiversity of Nagrala lake Bhadrawati, district-Chandrapur (M.S.). Int Res J Sci Eng 6(1):17-19

Billore DK, Vyas IN (1981) Distribution and production of macrophytes in pichhola lake, Udaipur. Dnt J Ecol Env-Sci 7:45-54

Bini LM, Thomas SM, Murphy KJ, Camargo AFM (1999) Aquatic Macrophyte distribution in relation to water and sediment conditions in the itaipu reservoir, Brazil. Hydrobiologia 415:147-154

Boyd CE (1982) Water quality management for pond fish culture. Agricultural Experiment Station, Auburn, Alabama, Birmingham Publishing Company, New York, Department of Fisheries and Allied Aquaculture

Cook CDK (1996) Aquatic and wetland plants of India. Oxford University Press, Oxford

Crowder AA, Bristow JM, King MR, Vander KS (1977) Distribution, seasonality and biomass of aquatic macrophytes in lake Opnicon. Nat Can 104:441-456

Devi CG, Sharma BM (2007) Studies on the diversity of the macrophytes in Awangsoipat Lake (Bishnupur), Manipur, India. In: Kandya AK, Gupta A (eds) Biodiversity conservation and legal aspect. Aviskar Publishers, Distributors, Jaipur, pp 62-71
Dey SC, Kar D (1989) Aquatic macrophytes of Lake Sone in Assam. Environ Ecol 7(1):253-254

Dhore M, Lachure PS (2014) Survey of Aquatic Macrophyte diversity in Yavatamal District, Maharashtra, India. Int J Life Sci 2(3):273-275

Dokulil MT, Jagsch A, George GD, Anneville O, Jankowski T, Wahl B, Lenhart B, Bleckner T, Teubner K (2006) Twenty years of spatially coherent deep water warming in lakes across Europe related to North-Atlantic oscillation. Limnol Oceanogr 51:2787-2793

Dwivedi BK, Pandey GC (2002) Physico-chemical factors and algal diversity of two ponds, (Girija and Maqubara Pond), Faizabad. Pollut Res 21:361-370

Dykyjova D (1971) Production, vertical structure and light profiles in littoral stands of reed-bed species. Hydrobiologia (Romania) $12: 361-376$

Dykyjova D (1978) Primary production and production processes in littoral plant communities. In: Dykyjova D, Kvet J (eds) Pond littoral ecosystems. Structure and functioning. Ecological studies, vol 28. Springer, Berlin

Edmondson WT (1959) Freshwater biology, 2nd edn. Wiley, New York, pp 1-1248

Gaikwad SR, Ingle KN, Thorat SR (2008) Study of zooplankton pattern and resting egg diversity of recently dried water bodies in north Maharastra region. J Environ Biol 29:353-356

Gay PW, Proop JLR (1993) Aspects of river pollution. Butterworths Scientific Publication, London

George DG, Marberly SC, Hewitt DP (2004) The influence of NorthAtlantic oscillation on the physics, chemistry and biology of four lakes in the English Lake District. Freshw Biol 49:760-774

Ghavzan NJ, Gunale VR, Mahajan DM, Shrike DR (2006) Effect of environmental factors on ecology and distribution of aquatic macrophytes. Asian J Plant Sci 5(5):871-880

Ghose BB, Basu AK (1968) Observation on estuarine pollution of the Hooghly by the effluents from a chemical factory complex at reshasa, West Bengal. Environ Health 10:209-218

Gulati RC (1964) Limnological studies on some North Indian Lakes and Reservoirs. Ph.D. Thesis. University, Delhi

Gupta S, Shukla DN (2006) Physico-chemical analysis of sewage water and its effect on seed germination and seedling growth of sesamum indicum. J Res Natl Dev 1:15-19

Gupta DP, Sunita SJP, Saharan JP (2009) Physiochemical analysis of ground water of selected area of Kaithal City (Haryana) India. Researcher 1(2):1-5

Hassan KY, Indabawa Kutama AS, Sani I (2013) Seasonal and spatial variation of the physico- chemical parameters in relation to some biological parameters of Kanye Dam Kano, Nigeria. Int J Appl Res Technol 2(7):31-38

Islam M (1990) Advance in plant sciences. 12:35

Jacklin Jemi R, Regini Balasingh GS (2011) Studies on physicochemical characteristics of freshwater temple ponds in Kanyakumari district (South Tamilnadu). Int J Geol Earth Environ Sci 1(1):59-62

Jayakumar P, Jothivel N, Thimmappa A, Paul VI (2009) Physicochemical characterization of a lentic water body from Tamilnadu with special reference to its pollution status. The Ecoscan 3(1\&2):59-64

Jeje CV, Fernando CK (1986) A practical guide to identification of nigeria zooplankton. Kainji Lake Institute, New Bussa, pp 89-99

Jha BC (1997) Salient ecological features of Mans and Chaurs of North Bihar and their fisheries. In: Fisheries enhancement of small reservoirs and flood plains lake in India, Bulletin 75 CIFRI, Barrackpore, pp. 167-173

Karanth KR (1987) Groundwater assessment development and management. Tata McGraw Hill Publishing Company Ltd., New Delhi, pp 725-726 
Kataria HC, Quershi HA, Iqbal SA, Shandilya AK (1996) Assessment of water quality of Kolar reservoir in Bhopal (M.P.). Pollut Res 15(2):191-193

Keramat AA (2008) Environmental impact on nutrient discharges by aquaculture waste water at on the Haraz river. J Fish Aquat Sci $3: 275-279$

Kodarkar MS (1996) Conservation of lakes. IAAB Publication No. 3, IAAB, Hyderabad

Kudesia VP (2000) Trace and macronutrient elements in drinking water. Pragathi Prakashan, Meerut, pp 1-216

Kumar N (1997) A view on freshwater environment. Ecol Environ Conserv 3:3-4

Kumar R, Pandit AK (2005) Community architecture of macrophytes in Hokarsar wetland, Kashmir. Ind J Environ Ecoplan 10:565-573

Kumar V, Qureshi TA, Shukla JP (2007) Ecological Status and zooplankton diversity of Sikanderpur reservoir, Basti (U.P). J Ecophysiol Occup Health 7:79-85

Kutama AS, Hassan KY, Ibrahim Y (2011) Algal diversity in relation to physico-chemical parameters of three ponds in Kano metropolis, Nigeria. Biosci Res Commun 22(6):321-328

Mahananda HB, Mahanand MR, Mohanty BP (2005) Studies on the physico-chemical and biological parameters of a fresh water pond ecosystem as an indicator of water pollution. Ecol Environ Conserv 11(3-4):537-541

Mathew PM (1978) Limnological investigations on the plankton of Govindgarh lake and its correlation with physico-chemical factors, primary productivity and fish production- Ph.D. Thesis, Agra Univ. Agra

Melzer A (1999) Aquatic macrophytes as tools for lake management. Hydrobiologia 396:181-190

Mitra AK (1995) Water quality of some tributaries of Mahanadi. J Environ Health 37:26-36

Morrissette DG, Mavinic DS (1978) BOD test variables. J Environ Eng Div EP 6:1213-1222

Moss B (1972) Studies on gull lake, Michigan II. Eutrophication evidence and prognosis. Freshw Biol 2:309-320

Mukhopadhyay SK, Chattopadhyay B, Goswami AR, Chatterjee A (2007) Spacial variations in zooplankton diversity in waters contaminated with composite effluents. J Limnol 66:97-106

Murugesan S, Kumar DS, Rajan S, Chandrika D (2004) Comparative study of ground water resources of east and west region of Chennai, Tamilnadu. Nat Environ Pollut Technol 3(4):495-499

Naik S, Purohit KM (1997) Status of water quality at Bondamunda of Rourkela industrial complex part 1, physicochemical parameters. Indian J Environ Protect 18(5):346-353

Narayan R, Saxena KK, Chauhabn S (2007) Limnological investigations of Texi temple pond in district Etawah (U.P.). J Environ Biol 28(1):155-157

Pandey AK, Pandey GC (2003) Physico-chemical charateristics of city sewage discharge into Saryu at Faizabad-Ayodhya. Himal J Environ Zool 17:85-91

Pandit AK (1984) Role of macrophytes in aquatic ecosystems and management of freshwater resources. J Environ Manag (London) 18:73-88

Patil DB, Tijare RV (2001) Studies on water quality of godchiroli lake. Pollut Res 20:257-259

Penning WE, Dudley B, Mjelde M, Hellsten S, Hanganu J, Kolada A, van den Berg M, Poikane S, Phillips G, Willby N et al (2008) Using aquatic macrophyte community indices to define the ecological status of european lakes. Aquat Ecol 42:253-264

Poikane S, Birk S, Böhmer J, Carvalho L, de Hoyos C, Gassner H, Hellsten S, Kelly M, Lyche Solheim A, Olin M et al (2015) A hitchhiker's guide to european lake ecological assessment and intercalibration. Ecol Indic 52:533-544
Prakash NJ (2004) Studies on groundwater quality of Magadi taluk, Bangalore rural district, Karnataka. Ph.D. Thesis, Kuvempu University, India, pp 1-230

Rao AM (2001) An environmental assessment on SIPCOT industrial complex, Cuddalore, Tamilnadu in relation to water pollution and its ethical implications. Ph.D. Thesis, Annamalai University, India, pp 1-7

Rooney N, Kalff J (2000) Inter-annual variation in submerged macrophyte community biomass and distribution: the influence of temperature and lake morphometry. Aquat Bot 68:321-335

Saha S, Mandal A, Sahoo D (2017) Study of physico-chemical parameters of three different urban pond water of Nadia district, WestBengal, India. Int J Fish Aquat Sci 5(6):23-27

Salaskar PB (1998) Some environmental aspects of Powai lake. Ph.D. Thesis, Mumbai University, Mumbai

Sastry KV, Rathee P, Sukla V (1999) Ground water characteristics of Rohtak and Bahadurgarh. Environ Ecol 17:105-108

Sehgal KL (1983) Planktonic copepods of freshwater ecosystems. Interprint, New Delhi

Sharma BK (1998) Faunal diversity in India. In: Alferd JRB, Das AK, Sanyal AK (eds) Rotifera: faunal diversity of India. Zoological Survey of India, Envis Centre, Kolkata, pp 57-70

Sharma BK, Michael RG (1987) Review of taxonomic studies on freshwater Cladocera from India with remarks on biogeography. Hydrobiologia 145:29-33

Shinde SE, Pathan TS, Raut KS, More PR, Sonwane DL (2010) Seasonal variations in physico-chemical characteristics of HarsoolSavangi dam, Aurangabad, India. The Ecoscan 4(1):37-44

Shinde SE, Pathan TS, Raut KS, More PR, Sonawane DL (2011) Studies on the physico-chemical parameters and correlation coefficient of Harsool-savangi Dam, District Aurangabad, India. Middle-East J Sci Res 8(3):544-554

Short FT, Neckles HA (1999) The effects of global climate change on seagrasses. Aquat Bot 63:169-196

Silva TSF, Costa MPF, Melack JM, Novo EMLM (2008) Remote sensing of aquatic vegetation: theory and applications. Environ Monit Assess 140:131-145

Singh RP, Mathur P (2005) Investigation of variation in physicochemical characteristics of a fresh water reservoir of Ajmer city, Rajasthan. Indian J Environ Sci 9:57-61

Skubinna JP, Coon TG, Batterson TR (1995) Increased abundance and depth of submersed macrophytes in response to decreased turbidity in saginaw bay, lake huron. J Gt Lakes Res 21:476-488

Sondergaard M, Johansson LS, Lauridsen TL, Jørgensen TB, Liboriussen L, Jeppesen E (2010) Submerged macrophytes as indicators of the ecological quality of lakes. Freshw Biol 55:893-908

Suganan VV (1997) Flood plain wetlands small water bodies' culture based fisheries and enhancement conceptual frame work and definition: In: Fisheries enhancement of small reservoir and Flood Plain Lake in India, Bulletin-15 CIFRI, Barrackpore

Sunkad BN (2008) Water quality assessment of Kanabargi water body (Belgaum). Environ Ecol 26:191-194

Tripathi NN, Shukla JP, Mishra M (2008a) Seasonal variations in hydrological parameters and biodiversity of Icthyofauna of Sikandrapur reservoir, Basti (U.P.). J Ecophysiol Occup Health 8:73-85

Tripathi NN, Shukla JP, Mishra M (2008b) Seasonal variations in water quality and biological diversity of of Sikandrapur reservoir, Basti (U.P.). J Adv Zool 29(2):109-117

Tripathy PK, Adhikary SP (1990) Preliminary studies on the water pollution of river Nandira. Indian J Environ Health 32(4):363-368

Unni KS (1971) An ecological study of the macrophytic vegetation of the doodhari lake, Raipur, M.P., India: distribution and seasonal changes in aquatic plants. Hydrobiologia 37:139-155

Venkataraman K (1999) The freshwater Cladocera (Crustacea: Branchipoda) Zoological survey of India, State Fauna series 3: Fauna of west Bengal Part 10:251-284

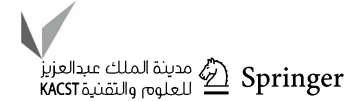


Wahane MS, Deshmukh UB, Gedam YB (2017) Study of aquatic macrophyte diversity of sakharwahi reservoir of Sakharwahi Village, Chandrapur District (Maharashtra), India. Int J Res Biosci Agric Technol 2:467-471

Zutshi DP, Subla BA, Khan MA, Wanganeo A (1980) Comparative limnology of nine lakes of Jammu and Kashmir, Himalaya. Hydrobiologia 72:101-112
Publisher's Note Springer Nature remains neutral with regard to jurisdictional claims in published maps and institutional affiliations. 